\title{
The original mammal fauna of the Pilbara biogeographic region of north-western Australia
}

\author{
Alexander Baynes ${ }^{1}$ and Matthew C. McDowell ${ }^{2}$ \\ ${ }^{1}$ Research Associate, Department of Earth and Planetary Sciences, Western Australian Museum, Locked Bag 49, \\ Welshpool DC, Western Australia 6986, Australia. Email: alex.baynes@museum.wa.gov.au \\ ${ }^{2}$ Mammal Section, South Australian Museum, North Tce, Adelaide South Australia 5000; and School of Biological \\ Science, Flinders University of South Australia, PO Box 2100, Adelaide, South Australia 5001, Australia.
}

\begin{abstract}
The hills and ranges of the Pilbara contain large numbers of caves, but only a miniscule proportion of these holds mammal remains that can be used to reconstruct the original (i.e. pre-European) fauna. During two field seasons in 1985 and 2004, only 12 sites with bones were discovered. Material from three other sites lodged in the collections of the Western Australian Museum was also used. Thirty-six native mammal species plus the introduced House Mouse were identified from cave surface remains. Compared with the fauna known from live-caught specimen records and the results of the Pilbara Biodiversity Survey, rodent species are comprehensively represented among the remains, dasyurid marsupials and bandicoots are moderately well represented, macropodoids are poorly represented, and bats (except two cave-roosting species) hardly represented at all. Results of this study indicate that the Central Rock-rat (Zyzomys pedunculatus), and probably the Golden-backed Tree-rat (Mesembriomys macrurus), originally occurred throughout the Pilbara ranges. Chuditch (Dasyurus geoffroii) is recorded from the Pilbara for the first time, suggesting that it may have occurred in the lowlands, while Northern Quoll (D. hallucatus) occupied the ranges. New records of Melomys burtoni and Pseudomys fieldi represent substantial extensions of geographic range. Overall, these results confirm the Pilbara as the western outpost of several northern mammal species, but show that the original fauna is less distinctive than previously thought, with a higher proportion of species widespread in the arid zone.
\end{abstract}

\section{INTRODUCTION}

The original (i.e. immediately pre-European) nonvolant mammal fauna of the Pilbara biogeographic region is incompletely known. The holotype of Mesembriomys macrurus (Peters, 1876) was collected from a mainland creek on the southern side of Mermaid Strait in the western Dampier Archipelago (Mahoney and Richardson 1988), but the inland Pilbara was not visited by $19^{\text {th }}$ century collectors of mammals (Glauert 1950; Ride 1968).

The mammal collection of the Western Australian Museum contains a small number of specimens received during the 1930s and 1940s from Pilbara pastoral stations, but the mammal fauna remained relatively unknown until the 1950s. The Western Australian Museum sent an expedition to the Hamersley Range in July and August 1958. Ride (1959) reported that the expedition obtained, apart from many insects, birds, reptiles and fish, about 50 specimens of 13 species of mammals. The specimens from the expedition are difficult to trace in the Museum mammal collection because they were not registered in a single group, but 56 specimens representing 11 species (one, Taphozous hilli Kitchener, 1980a, not recognised as distinct at the time) have been found (Appendix 1). The main collecting methods used were firearms and shelter destruction. This approach produced 34 kangaroo specimens, 18 bats, four dasyurids and no rodents. One of the most interesting specimens is the Planigale, M3432, which Archer (1976) considered to possibly represent an undescribed species within the genus. Far more mammal specimens resulted from collecting work by E.H.M. ('Tim') Ealey and colleagues on Abydos, Eginbah, Mount Edgar, White Springs and Woodstock Stations in the north-eastern Pilbara between 1953 and 1962 (Archer 1975). The collections of the Western Australian Museum contain at least 148 specimens representing 15 species of non-volant mammals collected by them (including Pseudantechinus roryi Cooper, Aplin and Adams, 2000, not recognised as distinct at the time). The Ealey collection provided most of the type series of Dasykaluta rosamondae (Ride, 1964), the first specimen of Ningaui timealeyi Archer, 1975, named after Ealey, and the first specimens of Pseudomys chapmani Kitchener, 1980b 
(Appendix 1). This work was followed by further collecting in the Pilbara, in particular by A.M. Douglas, who concentrated on bats, and W.H. Butler. These collections contained few specimens of mammal species that fall within the critical weight range (mean adult weight of $35 \mathrm{~g}$ to $5500 \mathrm{~g}$ ) identified by Burbidge and McKenzie (1989), and in particular no large rodents.

In subsequent decades, biological surveys of proposed resource developments and national parks (e.g. Dunlop and Sawle 1983), and a survey by the Western Australian Museum of the AbydosWoodstock Reserve (How et al. 1991; How and Cooper 2002), have resulted in many mammal specimens being added to the collections of the Western Australian Museum. These have included some additions to the general Pilbara non-volant mammal fauna, but not of species of the critical weight range (Gibson and McKenzie 2009). However, faunas from mammal remains from the caves in the karst limestone of Cape Range to the west of the Pilbara (Kendrick and Porter 1974; Baynes and Jones 1993), suggested that northwestern Australian non-volant mammal faunas once included several more species.

\section{MATERIALS AND METHODS}

Not only deep limestone caves but also small caves and holes in cliffs and 'breakaway' mesas can contain remains of vertebrates, particularly mammals, accumulated by predators that used the caves as shelters. In general the most important of these are Barn Owls, Tyto alba. Many mammal species have suffered drastic range reductions (some to extinction) since the arrival of Europeans in Australia, and fossil material has been used to reconstruct their past distributions and the original faunas of regions (e.g. Lundelius 1957; Kendrick and Porter 1974; Baynes 1990; Baynes and Baird 1992; Baynes and Jones 1993; McDowell and Medlin 2010). The vertebrate palaeontological collections of the Western Australian Museum contain many samples of such remains collected throughout the State during the 1960s and 1970s. Only one of these, however, is from the Pilbara: registration numbers 76.6.21-76.6.25, collected by W.H. Butler in 1976 at Marandoo near Mt Bruce. Although small, this sample includes the first remains identified from the Pilbara of four medium to large rodent species-Notomys longicaudatus, Pseudomys desertor, Pseudomys nanus and Rattus tunneyi.

Two periods of dedicated field work to attempt to find more such material in the Pilbara were carried out by A.B. and Thomas A. Smith between 25 July and 9 August 1985 and by the authors and T.A. Smith from 13 to 27 August 2004, as part of the Pilbara Biodiversity Survey (McKenzie et al. 2009). Very large numbers of rock shelters and rock overhangs were searched each time but very little was found. In 1985, only one large sample was discovered, at Coppin Gap in the east Pilbara. Small

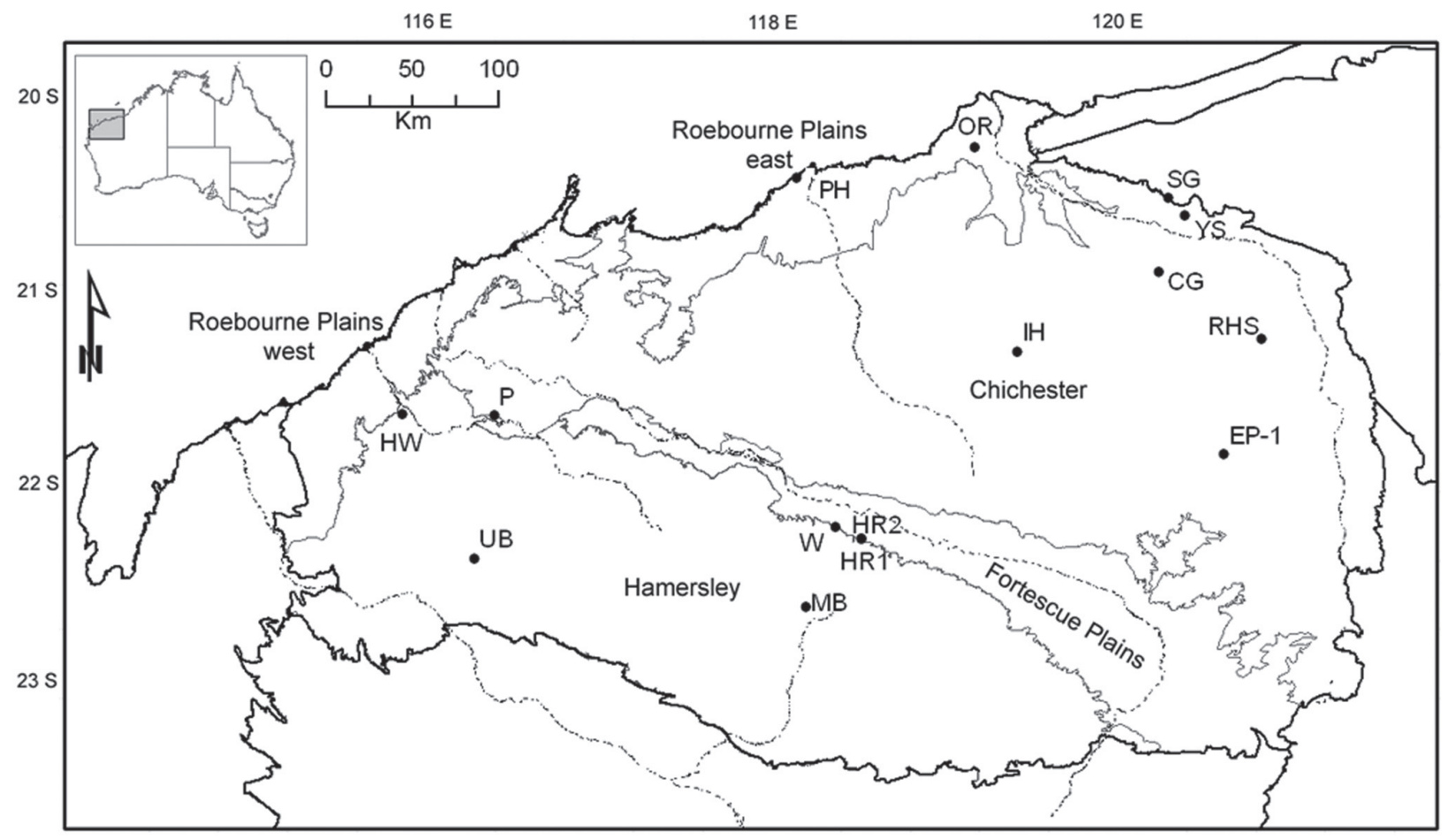

Figure 1 Location of the sites in which mammal remains have been found in the Pilbara biogeographic region. The boundaries of the region are shown in bold, and the four (named) sub-regions in stipple. For abbreviations of site names see Results section. 
samples were found on Yarrie and Pilga Stations in the east Pilbara, near Wittenoom in the Hamersley Range, and near Urandy Bore and Pannawonica in the west Pilbara. A medium-sized sample was found at Shay Gap, just over the eastern boundary of the Pilbara bioregion. In 2004, one large sample was found in a breakaway near Herbert Well on Yarraloola Station in the west Pilbara, and two small samples in a valley in the northern face of the Hamersley Range. Further substantial samples were also collected from a large sinkhole in the Ripon Hills, east Pilbara, previously discovered and sampled by P.G. Kendrick and J. Angus in November 1997.

In the laboratory, identifiable bones (mainly jaws) were sorted from the samples, and identified by comparison with material in the vertebrate palaeontological and modern mammal collections of the Western Australian and South Australian Museums.

\section{RESULTS}

\section{Sites}

Site details are given in west to east order. The positions of the sites within the Pilbara biogeographic region are shown in Figure 1.

'Herbert Well' (HW). Tubular hole in a breakaway cliff face north of Herbert Well on Yarraloola Station, at $21^{\circ} 39^{\prime} 22^{\prime \prime} \mathrm{S} 115^{\circ} 54^{\prime} 07^{\prime \prime} \mathrm{E}$, WGS 84, $91 \mathrm{~m}$, A. Baynes, M.C. McDowell and T.A. Smith, 18 August 2004.

'Urandy Bore' (UB). Breakaway caves south of Urandy Bore at $22^{\circ} 25^{\prime} \mathrm{S} 116^{\circ} 18^{\prime} \mathrm{E}, \mathrm{A}$. Baynes and T.A. Smith, 5 August 1985.

'Pannawonica' (P). Cave in north side of mesa $10 \mathrm{~km}$ ESE of Pannawonica, MR 394 035, 2140'S $116^{\circ} 25^{\prime}$ E, A. Baynes and T.A. Smith, 4 August 1985.

'Mt Bruce' (MB). Floor of breakaway cave $6 \mathrm{~km}$ SSE of Mt Bruce, on the former Marandoo iron ore prospect, $22^{\circ} 40^{\prime} \mathrm{S} 118^{\circ} 10^{\prime} \mathrm{E}$, W.H. Butler, 26 April 1976. Western Australian Museum vertebrate palaeontological collection, catalogue numbers 76.6.21-76.6.25.

'Wittenoom' (W). Hole in low cliff $2 \mathrm{~km}$ ESE of Wittenoom townsite, MR 388 387, 22 ${ }^{\circ} 15^{\prime} \mathrm{S} 118^{\circ} 20^{\prime} \mathrm{E}$, PIL3, A. Baynes and T.A. Smith, 26 July 1985. Field number ABRS 107.

Hamersley Range site 1 (HR1). Small cave in a valley in the northern face of the Hamersley Range, $22^{\circ} 18^{\prime} 26^{\prime \prime} \mathrm{S} 118^{\circ} 28^{\prime \prime} 32^{\prime \prime} \mathrm{E}$, WGS 84, $517 \mathrm{~m}$, T.A. Smith and A. Baynes, 15 August 2004.

Hamersley Range site 2 (HR2). Very small cave in a valley in the northern face of the Hamersley

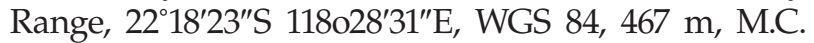
McDowell, A. Baynes and T.A. Smith, 15 August 2004.

Port Hedland $(\mathrm{PH})$. Limestone ridge north of the airport, from surface to depth of $1 \mathrm{ft}(30 \mathrm{~cm})$ in pothole in honeycombed limestone ridge intersecting mud flats, $20^{\circ} 25^{\prime} \mathrm{S} 118^{\circ} 06^{\prime} \mathrm{E}$, E. Atkins (Utah Construction Co.), August 1965. Western Australian Museum vertebrate palaeontological collection, catalogue numbers 65.10.206-65.10.211.

Ord Ranges (OR). Small hole in an outcrop at about $20^{\circ} 15^{\prime} \mathrm{S} 119^{\circ} 05^{\prime} \mathrm{E}, \mathrm{A}$. Baynes and T.A. Smith, 1 August 1985.

Island Hill (IH). Small caves in Island Hill, Pilga Station, $21^{\circ} 19^{\prime} \mathrm{S} 119^{\circ} 20^{\prime} \mathrm{E}$, PIL1, A. Baynes and T.A. Smith, 28 July 1985. Field numbers ABRS 108/1, 108/2.

Coppin Gap (CG). Overhang in rocks at top of scree slope on eastern side of Coppin Gap, 2053'11"S 12007'03"E, PIL1, A. Baynes, 29 July 1985. Field number ABRS 109.

Shay Gap (SG). Cave in sandstone escarpment on west side of townsite, $20^{\circ} 29^{\prime} 55^{\prime \prime} \mathrm{S} 120^{\circ} 09^{\prime} 44^{\prime \prime} \mathrm{E}$, GSD1, A. Baynes and T.A. Smith, 31 July 1985. Field number ABRS 111.

Yarrie Station (YS). Cave in hill at $20^{\circ} 35^{\prime} 14^{\prime \prime} \mathrm{S}$ $120^{\circ} 15^{\prime} 21^{\prime \prime}$ E, PIL1, A. Baynes and T.A. Smith, 30 July 1985. Field number ABRS 110.

East Pilbara sinkhole (EP-1). Deep vertical sinkhole in dolomite at $21^{\circ} 50^{\prime} \mathrm{S} 120^{\circ} 30^{\prime} \mathrm{E}$, bone material collected by R. Darren Brooks, 17 July 1994, held by Western Australian Museum (BES 4389).

Ripon Hills sinkhole (RHS). Large sinkhole in Ripon Hills at $21^{\circ} 13^{\prime} 27^{\prime \prime} S 120^{\circ} 41^{\prime} 40^{\prime \prime}$ E, WGS 84, $396 \mathrm{~m}$. Huge overhangs on northern (Nth) and southern (Sth) sides of central rock pile. Material previously collected from the northern side by Peter Kendrick (PK) in November 1997, and held at the Western Australian Museum. Further samples were collected from both northern (B2, T1) and southern (T2) 'caves' and the cave floor surface (S) by A. Baynes, M.C. McDowell and T.A. Smith, 21-23 August 2004.

\section{Fauna}

The mammal species identified from the remains from the various Pilbara sites are listed in Table 1. Most species are represented by well-preserved material, particularly in the large samples, giving rise to confident identifications. Dasyurus geoffroii, however, is recorded only from the Wittenoom site, in which the mammal remains consist of small broken bone fragments and isolated teeth. The $D$. geoffroii specimen consists of only a small fragment of left dentary with the alveoli for $\mathrm{M}_{4^{\prime}}$ but this is sufficient for it to be confidently distinguished from Isoodon on shape and the smaller D. hallucatus on size. Two sites contain other interesting specimens that cannot be identified to species. The material from the Wittenoom site also includes a lower permanent premolar cap of a small macropodid. 
It is closest in form to that of Lagorchestes hirsutus, but the match is not exact and it has therefore not been identified beyond Macropodidae indet. The specimens recorded as Macropodidae indet. from the Herbert Well and Hamersley Range 1 sites (Table 1) consist of fragments of long bones of large kangaroos of indeterminable species and represent other taxa. The Port Hedland site material includes a small dasyurid right dentary (Western Australian Museum vertebrate palaeontological collection number 65.10.207) with the first three lower molars in place; unfortunately these are very worn. The jaw is similar in size to those of Sminthopsis ooldea and S. youngsoni, but the molars appear broader, and there are only alveoli for two premolars, whereas species of Sminthopsis all have three. This specimen is therefore not identifiable beyond Dasyuridae indet. The Dasyuridae indet. from site B2 in the Ripon Hills sinkhole (Table 1) consist of edentulous jaws of other taxa, not identifiable beyond family level.

The modern mammal fauna of the Pilbara (i.e. that based upon live-caught animals) is listed in Table 2, and compared with the fauna obtained from cave remains from the Pilbara, and the original mammal faunas of Cape Range peninsula and southern mainland Carnarvon Basin. There are slight differences between the faunas listed in Table 2 and those in their sources, including Gibson and McKenzie (2009), whose faunal list (their Table 1) includes information provided by our study. Species that cannot be distinguised beyond generic level as cave remains, such as Dasycercus spp., are listed as sp. indet. in Table 2. Lagorchestes hirsutus is listed in the fauna by Gibson and McKenzie (2009). This record is based upon a preliminary identification of the premolar from the Wittenoom cave site, that, as noted above, is now not considered to be specifically identifiable. Leporillus apicalis is listed in the fauna by Gibson and McKenzie (2009). The source of this record is unclear, as the northern limits of the species' range lie in the Carnarvon and Gascoyne regions. Leporillus conditor was not recorded from any of the Cape Range cave samples studied by Baynes and Jones (1993), but remains of the species have subsequently been found in a cave in foothills on the eastern side of the Range (A. Baynes, unpublished observation). Pseudomys fieldi has been identified in remains from the Ripon Hills sinkhole site since Gibson and McKenzie (2009) was completed.

Comparison of mammal faunas from modern and cave records (Tables 1 and 2) shows two general patterns. Most bat species are poorly represented in the cave material, although remains of the caveroosting genera Taphozous and Macroderma were found; and there is a consistency between the deposits in the non-volant mammal faunas, which include a bandicoot and medium to large rodent species now lost from the region. The variation in representation of species, particularly small dasyurids, between the subsamples from the Ripon Hills sinkhole suggests that even the large aggregate sample from that site may not be large enough to contain all the species in the original local fauna.

\section{DISCUSSION}

\section{How representative are the fossil samples?}

Three factors bias samples of mammal remains in caves compared to the communities from which they are drawn: the sample size, the accumulating agent and the timing of accumulation. The nature of the statistical relationship between sample size and number of species detected (e.g. May 1975) dictates that no practical sample will contain a completely comprehensive local mammal fauna, even without the taphonomic filter of the accumulating agent or agents. The most important accumulating agent in most caves in arid Australia is the Barn Owl, Tyto alba. Obviously, there is an upper weight limit to the mammal species that it can catch and eat, at about the size of an adult rat; although it can prey upon juveniles of bandicoots and rat-kangaroos (Higgins 1999). A further bias is introduced by the nomadic behaviour of Barn Owls (Morton and Martin 1979). This is an adaptation to the population variations of native rodents. While the populations of insectivorous marsupials of the arid zone remain at relatively constant, but low, levels (e.g. Reid et al. 1993; Heywood and Pavey 2002), those of the local rodents tend to fluctuate through several fold (e.g. Finlayson 1939; Newsome and Corbett 1975), with peaks following major rain events (e.g. How et al. 1991; Reid et al. 1993; Dickman et al. 1999; McDowell and Medlin 2009). Barn Owls move to take advantage of these booms in rodent numbers (Schodde and Mason 1980), and therefore contribute most bones to deposits when rodent numbers are locally high. Both the high relative abundance of the living rodents, and probably the owls' search images for these species, bias the resulting accumulations of remains toward disproportionately high rodent and low dasyurid relative abundances (e.g. Morton and Martin 1979; Baynes and Baird 1992; McDowell and Medlin 2009). This effect biases representation of species among remains in cave deposits in favour of rodents.

\section{The original non-volant mammal fauna of the Pilbara}

As noted above, the results (Table 1) suggest that the original non-volant mammal fauna was fairly constant throughout the Pilbara. For reasons 


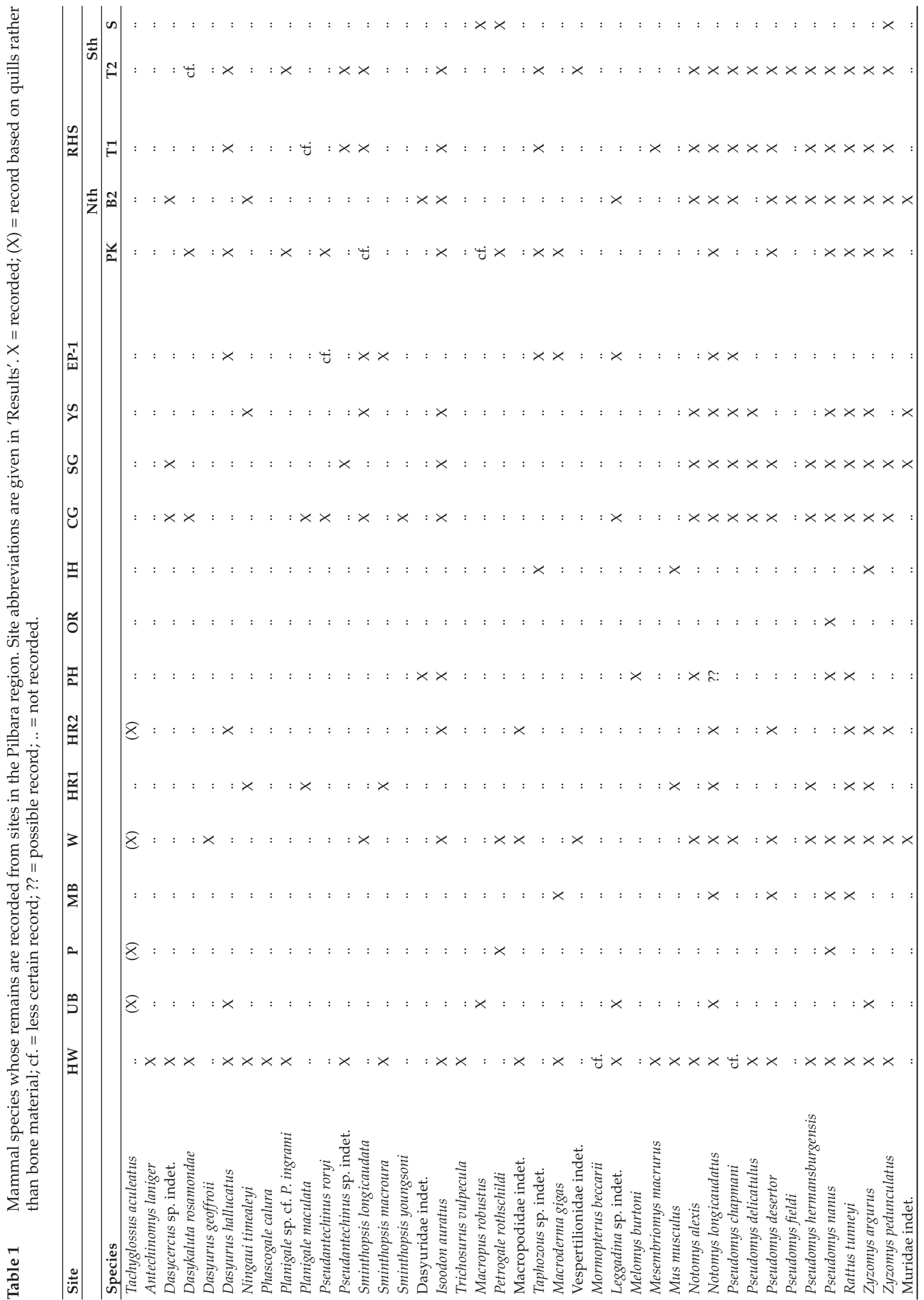


Table 2 The original native mammal fauna of the Pilbara, identified from remains from caves (data from this study) and modern native mammal fauna (data from W.A. Museum specimen records; Gibson and McKenzie 2009; McKenzie and Bullen 2009), compared with the total (original + modern) native mammal faunas recorded from the mainland southern Carnarvon Basin (i.e. excluding the Shark Bay peninsulas and islands) (data from Baynes 2000; McKenzie et al. 2000; McKenzie and Muir 2000) and Cape Range (data from Baynes and Jones 1993). X = recorded; ? = less certain record; .. = not recorded. ${ }^{*}=$ locally extinct on the Pilbara mainland; ${ }^{* *}=$ totally extinct. \# discussed in Results section.

\begin{tabular}{|c|c|c|c|c|}
\hline Species & Carnarvon Basin & Cape Range & Original Pilbara & Modern Pilbara \\
\hline Tachyglossus aculeatus & $x$ & $x$ & $x$ & $x$ \\
\hline Antechinomys laniger & $x$ & $x$ & $x$ &.. \\
\hline Dasycercus sp. indet. & $x$ & $x$ & $x$ & $x$ \\
\hline Dasykaluta rosamondae & $?$ & $x$ & $x$ & $x$ \\
\hline Dasyurus geoffroii ${ }^{*}$ & $x$ & $x$ & $x$ &.. \\
\hline Dasyurus hallucatus &.. & $x$ & $x$ & $x$ \\
\hline Ningaui timealeyi & .. & $x$ & $x$ & $x$ \\
\hline Phascogale calura* & $x$ & $x$ & $x$ &.. \\
\hline Planigale sp. cf. P. ingrami &.. &.. & $x$ & $x$ \\
\hline Planigale maculata & .. & $x$ & $x$ & $x$ \\
\hline Pseudantechinus roryi & .. &.. & $x$ & $x$ \\
\hline Pseudantechinus woolleyae &. &.. &.. & $x$ \\
\hline Pseudantechinus sp. indet. &.. & $x$ & $x$ &.. \\
\hline Sminthopsis dolichura & $x$ & .. & .. &.. \\
\hline Sminthopsis hirtipes & $x$ & .. &.. &.. \\
\hline Sminthopsis longicaudata &.. & $x$ & $x$ & $x$ \\
\hline Sminthopsis macroura & $x$ & $x$ & $x$ & $x$ \\
\hline Sminthopsis ooldea & .. & $?$ & .. & $x$ \\
\hline Sminthopsis youngsoni & $x$ & $x$ & $x$ & $x$ \\
\hline Chaeropus ecaudatus ${ }^{* *}$ & $x$ &.. &.. &.. \\
\hline Isoodon auratus* & $x$ & $x$ & $x$ & $x$ \\
\hline Perameles bougainville* & $x$ & $x$ & .. & .. \\
\hline Macrotis lagotis & $x$ & $x$ & .. & $x$ \\
\hline Trichosurus vulpecula &.. & $x$ & $x$ & $x$ \\
\hline Bettongia lesueur* & $x$ & $x$ & .. & .. \\
\hline Lagorchestes conspicillatus & .. & .. &.. & $x$ \\
\hline Macropus robustus & $x$ & $x$ & $x$ & $x$ \\
\hline Macropus rufus & .. & $x$ &. & $x$ \\
\hline Petrogale lateralis &. & $x$ &.. & $x$ \\
\hline Petrogale rothschildi &. &. & $x$ & $x$ \\
\hline Pteropus alecto & $x$ &. &. & $x$ \\
\hline Pteropus scapulatus & $x$ & $x$ &. & $x$ \\
\hline Saccolaimus flaviventris & $x$ &.. & .. & $x$ \\
\hline Taphozous georgianus & $\mathrm{x}$ & $x$ & $?$ & $x$ \\
\hline Species & Carnarvon Basin & Cape Range & Original Pilbara & Modern Pilbara \\
\hline
\end{tabular}


Table 2 (continued)

\begin{tabular}{|c|c|c|c|c|}
\hline Taphozous hilli & .. & .. & .. & $x$ \\
\hline Macroderma gigas &.. &.. & $x$ & $x$ \\
\hline Rhinonicteris aurantius &.. &.. &.. & $x$ \\
\hline Chalinolobus gouldii & $x$ & $x$ &.. & $x$ \\
\hline Chalinolobus morio &.. &. &.. & $x$ \\
\hline Nyctophilus arnhemensis &.. &.. &.. & $x$ \\
\hline Nyctophilus bifax daedalus &.. & .. &.. & $x$ \\
\hline Nyctophilus geoffroyi geoffroyi & $x$ &.. &.. & $x$ \\
\hline Nyctophilus geoffroyi pallescens &.. &. &.. & $x$ \\
\hline Scotorepens balstoni & $x$ & .. &. & .. \\
\hline Scotorepens greyii & $x$ & .. &.. & $x$ \\
\hline Vespadelus finlaysoni & $x$ & $x$ &.. & $x$ \\
\hline Chaerephon jobensis & $x$ &.. &.. & $x$ \\
\hline Mormopterus beccarii & $x$ &.. & $?$ & $x$ \\
\hline Mormopterus loriae &.. &. &. & $x$ \\
\hline Mormopterus planiceps & $x$ &.. & .. & .. \\
\hline Tadarida australis & $x$ & $x$ &.. & $x$ \\
\hline Hydromys chrysogaster &.. &. &.. & $x$ \\
\hline Leggadina lakedownensis & $?$ & $?$ & $?$ & $x$ \\
\hline Leporillus apicalis**$^{* *}$ & $x$ & $x$ &.. & ..\# \\
\hline Leporillus conditor* & $x$ & X\# &.. & .. \\
\hline Melomys burtoni* &. &.. & $x$ & .. \\
\hline Mesembriomys macrurus* &.. & $x$ & $x$ & .. \\
\hline Notomys alexis & $x$ & $x$ & $x$ & $x$ \\
\hline Notomys amplus** & $x$ & $x$ &.. & .. \\
\hline Notomys longicaudatus** & $x$ & $x$ & $x$ & .. \\
\hline Pseudomys albocinereus & $x$ &.. &.. & .. \\
\hline Pseudomys chapmani &.. & $x$ & $x$ & $x$ \\
\hline Pseudomys delicatulus &.. &.. & $x$ & $x$ \\
\hline Pseudomys desertor & $x$ & $x$ & $x$ & $x$ \\
\hline Pseudomys fieldi ${ }^{*}$ & $x$ & $x$ & X\# & .. \\
\hline Pseudomys hermannsburgensis & $x$ & $x$ & $x$ & $x$ \\
\hline Pseudomys nanus* & $x$ & $x$ & $x$ & .. \\
\hline Rattus tunneyi* & $x$ & $x$ & $x$ & .. \\
\hline Zyzomys argurus &.. &.. & $x$ & $x$ \\
\hline Zyzomys pedunculatus* & $x$ & $x$ & $x$ & .. \\
\hline Canis lupus & .. & $x$ & .. & .. \\
\hline
\end{tabular}


discussed in the section above, absence of a species from a particular sample is not necessarily meaningful. But where samples are large, the remaining differences between the faunas are mainly explicable in terms of the presence or absence of suitable habitat for the species around the sites. Thus, for example, remains of Leggadina are present in quite large numbers in the sample from the Herbert Well site because there are extensive plains (its preferred habitat) around the breakaway that contains that site, but are present in only very small numbers in one of the samples from the Ripon Hills sinkhole site, which is surrounded by rocky hills. Moreover, most of the Ripon Hills samples are larger than that from Herbert Well. Relative abundances of other rodent species similarly reflect the quantity of habitat around sites. For example, although the rock-rat Zyzomys pedunculatus is recorded from Herbert Well, it is present in only very low numbers, whereas its remains are quite abundant in the Ripon Hills sinkhole, and also in the caves of Cape Range (Baynes and Jones 1993). This pattern is consistent with the results obtained by Gibson and McKenzie (2009), whose analyses showed that substrate was the most important predictor of occurrence at a particular site for the small ground mammal species still extant in the Pilbara.

Among the most interesting records (Table 1) are those of Mesembriomys macrurus from both the Herbert Well site and Ripon Hills sinkhole, suggesting that the species originally had a much wider distribution in the Pilbara than previously indicated by the one modern specimen from the coast near Roebourne and fairly scarce remains in Cape Range cave deposits (Kendrick and Porter 1974; Baynes and Jones 1993). Although an arboreal species, extant populations in the north-west Kimberley have been recorded from a wide variety of habitats, ranging in density from rainforest to woodlands over hummock grassland and rugged sandstone screes (McKenzie and Kerle 1995). The animals spend quite a lot time on the ground, easily crossing open vegetation formations. Like many Australian rodents, M. macrurus is omnivorous, feeding on flowers, fruits and insects (particularly termites), and other vegetable foods (McKenzie and Kerle 1995); it is even reported to have a liking for marine molluscs (Watts and Aslin 1981). In the Pilbara, fig trees (Ficus platypoda) may have provided several habitat requirements of $M$. macrurus, including fruit and arboreal nesting sites. The site in the breakaway range near Herbert Well is situated in a deep gully containing several large fig trees. Fig trees also occur in the Cape Range (Keighery and Gibson 1993), sometimes marking the entrances to caves.

The results (Table 1) also suggest that Zyzomys pedunculatus occurred throughout the Pilbara ranges, something that was previously unknown. Notomys longicaudatus, too, was very widespread and is represented in many of the samples. Pseudomys fieldi was not previously known to have originally occurred in the Pilbara, and the Ripon Hills sinkhole record represents a substantial extension of range, east from the Cape Range and north from the Gibson Desert.

The most surprising record is that of Dasyurus geoffroii from the Wittenoom site. It has been thought (e.g. the distribution map in Serena and Soderquist 1995) that the species did not occur in the Pilbara, and that only D. hallucatus was present. The actual situation seems to have been more complex. Although the record of D. geoffroii is based upon a very fragmentary specimen, it appears to be a reliable identification. The Wittenoom site is in the northern foothills of the Hamersley Range, overlooking the Fortescue River valley. There is likely to have been ecological separation between the two species of Dasyurus, probably primarily by habitat, with $D$. hallucatus occurring in the rocky habitats of the ranges and D. geoffroii probably restricted to the valley and plain habitats in the region. The specimen in the Wittenoom site is probably from an individual caught in the valley and transferred into the site by its predator, most likely a Dingo on the basis of the highly fragmented nature of most of the mammal bones in the site. Occurrence of only D. hallucatus in the Ripon Hills site, both as remains and as a living animal observed by M.C. McDowell in August 2004, is consistent with this proposed pattern because that site is entirely surrounded by rocky hills. Although the two Hamersley Range sites, from one of which D. hallucatus is recorded (see Table 1), are in a similar situation to the Wittenoom cave, they are considerably higher and further into the Range, and neither appears suitable as a Dingo lair.

Melomys burtoni is probably recorded from just the Port Hedland site because the species originally had a very restricted distribution in the Pilbara, occurring only on the coast, possibly in or around the mangrove formations. The final record of particular interest is that of Phascogale calura in the Herbert Well site deposit. The significance of this is more difficult to assess because its apparent absence from the Ripon Hills sinkhole could be due to the fact that the small dasyurid material in that deposit is poorly preserved, generally fragmented and very difficult to identify. In this context it is unfortunate that no further material was obtained during the survey from the EP-1 sinkhole, because the bones from that site are beautifully preserved.

One species that appears to be under-represented in the cave deposits is Trichosurus vulpecula, which is recorded only from the Herbert Well site. 
Trichosurus vulpecula often uses caves as shelters, and its remains are common in the Cape Range caves (Baynes and Jones 1993). It is particularly surprising that no remains of it have been found in the Ripon Hills sinkhole. It is possible that most of the Pilbara caves are not deep or cool enough to provide shelter of adequate quality for this species. Although the Ripon Hills sinkhole may provide a suitable shelter for the species, it may be surrounded by such inhospitable terrain that Trichosurus was not able to reach it.

\section{Biogeography}

In Table 2 the Pilbara mammal fauna is compared with those of the mainland southern Carnarvon Basin and the Cape Range (in the northern Carnarvon Basin) to the west. Generally, the faunas are quite similar, but from south-west to north-east there is a loss of southern species and addition of or replacement by northern species.

The original ranges of three mammal species widespread in the drier inland of south-western Australia-Sminthopsis dolichura, Mormopterus planiceps and Pseudomys albocinereus-extended as far north as the southern mainland Carnarvon Basin, but no further. Sminthopsis hirtipes of the southern arid zone sandy habitats drops out in favour of the more northerly distributed $S$. youngsoni. Chaeropus ecaudatus originally reached its northern range limit in the southern Carnarvon Basin, and both species of Leporillus originally reached their northern range limits on the Cape Range peninsula.

Northern forms recorded from the Pilbara, and in some cases also the Cape Range, include Dasyurus hallucatus, Lagorchestes conspicillatus, Rhinonicteris aurantius, Nyctophilus arnhemensis, Nyctophilus bifax, Mormopterus loriae, Melomys burtoni, Mesembriomys macrurus, Pseudomys delicatulus and Zyzomys argurus. Of these, Mormopterus loriae and Melomys burtoni have or had coastal distributions because in these western parts of their ranges they are (or were) restricted to mangroves. Although Macroderma gigas is also widespread in northern Australia, its absence from the mainland Carnarvon Basin, including Cape Range, is probably related to cave morphology, because in pre-European times there were large colonies of the species further south in suitable west coast Tamala Limestone caves between Dongara and Yanchep (e.g. Lundelius 1957). As noted above, Dasyurus hallucatus was probably restricted to rocky habitats in both the Pilbara and Cape Range, and the lowland flats were occupied by D. geoffroii.

Habitat factors probably also explain presences and absences of some other species. The rocky habitat specialists Sminthopsis longicaudata and Zyzomys pedunculatus, which had extensive original ranges in the arid zone, are probably present in the Pilbara and Cape Range but absent from the southern Carnarvon Basin because the latter lacks suitable ranges. Conversely, remains of the sand habitat specialists Perameles bougainville and Notomys amplus are both very rare in Cape Range deposits (Baynes and Jones 1993) and not recorded from the Pilbara, even though both originally occurred in the Great Sandy Desert (Western Australian Museum record M1489 for Perameles; A. Baynes unpublished observation for N. amplus), as well as the southern Carnarvon Basin.

Finally, there is a group of mammal species restricted to north-western Australia: Dasykaluta rosamondae, Ningaui timealeyi, Petrogale rothschildi and Pseudomys chapmani. Of these, only Petrogale rothschildi is confined to the Pilbara. When their systematics are resolved, it is likely that the two species of Planigale recorded from the Pilbara will be added to this group.

\section{ACKNOWLEDGEMENTS}

The 1985 field work was financed by a grant to A. Baynes from the Australian Biological Resources Study. We thank CALM/DEC (through the auspices of Norm McKenzie) for funding for field work in 2004, and for contracts to collect the specimens in 2004 and write them up in 2007. Tom Smith provided skilled assistance during the field work. We are very grateful to Tom Smith and Sara Peet for sorting material from Herbert Well, Hamersley Range and Ripon Hills. Brent Johnson is thanked for assistance with specimen preparation. Gavin Prideaux provided advice on identification of macropodoid remains. We thanks our referees Anne Kerle and Jim Mead, and editor Alex George, for constructive suggestions that improved the paper.

\section{REFERENCES}

Archer, M. (1975). Ningaui, a new genus of tiny dasyurids (Marsupialia) and two new species, $N$. timealeyi and N. ridei, from arid Western Australia. Memoirs of the Queensland Museum 17: 237-249.

Archer, M. (1976). Revision of the marsupial genus Planigale Troughton (Dasyuridae). Memoirs of the Queensland Museum 17: 341-365.

Baynes, A. (1990). The mammals of Shark Bay, Western Australia (pp 313-325). In: Berry, P.F., Bradshaw, S.D. and Wilson, B.R. (eds), Research in Shark Bay: Report of the France-Australe Bicentenary Expedition Committee. Western Australian Musuem: Perth, Australia.

Baynes, A. (2000). Appendix 2. Original mammal faunas of the Carnarvon Basin, based on fossil material from the surfaces of small caves. Records of the Western Australian Museum, Supplement 61: 506-510.

Baynes, A. and Baird, R.F. (1992). The original mammal fauna and some information on the original bird fauna of Uluru National Park, Northern Territory. The 
Rangeland Journal 14: 92-106.

Baynes, A. and Jones, B.A. (1993). The mammals of Cape Range peninsula, north-western Australia. Records of the Western Australian Museum, Supplement 45: 207-225.

Burbidge, A.A. and McKenzie, N.L. (1989). Patterns in the modern decline of Western Australia's vertebrate fauna: causes and conservation implications. Biological Conservation 50: 143-198.

Cooper, N.K., Aplin, K.P. and Adams, M. (2000). A new species of false antechinus (Marsupialia: Dasyuromorphia: Dasyuridae) from the Pilbara region, Western Australia. Records of the Western Australian Museum 20: 115-136.

Dickman, C.R., Mahon, P.S., Masters, P. and Gibson, D.F. (1999). Long-term dynamics of rodent populations in arid Australia: the influence of rainfall. Wildlife Research 26: 389-403.

Dunlop, J.N. and Sawle, M. (1983). The small mammals of the eastern Pilbara and the Hamersley Range National Park. National Parks Authority of Western Australia Bulletin 1: 26-30.

Finlayson, H.H. (1939). On mammals from the Lake Eyre Basin. Part V. General remarks on the increase of murids and their population movements in the Lake Eyre Basin during the years 1930-1936. Transactions of the Royal Society of South Australia 63: 348-353.

Gibson, L.A. and McKenzie, N.L. (2009). Environmental associations of small ground-dwelling mammals in the Pilbara region, Western Australia. Records of the Western Australian Museum, Supplement 78: 91-155.

Glauert, L. (1950). The development of our knowledge of the marsupials of Western Australia. Journal of the Royal Society of Western Australia 34: 115-134.

Heywood, M.R. and Pavey, C.R. (2002). Relative importance of plague rodents and dasyurids as prey of barn owls in central Australia. Wildlife Research 29: 203-207.

Higgins, P.J. (ed.) (1999). Handbook of Australian, New Zealand and Antarctic birds, 4, Parrots to Dollarbirds. Oxford University Press: Melbourne, Australia.

How, R.A. and Cooper, N.K. (2002). Terrestrial small mammals of the Abydos Plain in the north-eastern Pilbara, Western Australia. Journal of the Royal Society of Western Australia 85: 71-82.

How, R.A., Dell, J. and Cooper, N.K. (1991). Vertebrate fauna. Ecological survey of Abydos-Woodstock Reserve, Western Australia. Records of the Western Australian Museum, Supplement 37: 78-125.

Keighery G.J. and Gibson, N. (1993). Biogeography and composition of the flora of the Cape Range peninsula, Western Australia. Records of the Western Australian Museum, Supplement 45: 51-85.

Kendrick, G.W. and Porter, J.K. (1974). Remains of a thylacine (Marsupialia: Dasyuroidea) and other fauna from caves in the Cape Range, Western Australia. Journal of the Royal Society of Western Australia 56: 116-122.

Kendrick, P.G. (2007). The non-volant vertebrate fauna of the Burrup Peninsula, Pilbara, Western Australia. The Western Australian Naturalist 25: 197-241.

Kitchener, D.J. (1980a). Taphozous hilli sp. nov. (Chiroptera:
Emballonuridae), a new sheath-tailed bat from Western Australia and Northern Territory. Records of the Western Australian Museum 8: 161-169.

Kitchener, D.J. (1980b). A new species of Pseudomys (Rodentia: Muridae) from Western Australia. Records of the Western Australian Museum 8: 405-414.

Lundelius, E.L. (1957). Additions to knowledge of the ranges of Western Australian mammals. The Western Australian Naturalist 5: 173-182.

Mahoney, J.A. and Richardson, B.J. (1988). Muridae (pp 154-192). In: Walton, D.W. (ed.), Zoological catalogue of Australia, 5, Mammalia. Australian Government Publishing Service: Canberra, Australia.

May, R.M. (1975). Patterns of species abundance and diversity (pp 81-120). In: Cody, M.L. and Diamond, J.M. (eds), Ecology and evolution of communities. Belknap Press: Cambridge, U.S.A.

McDowell, M.C. and Medlin, G.C. (2009). The effects of drought on prey selection of the barn owl (Tyto alba) in the Strzelecki Regional Reserve, north-eastern South Australia. Australian Mammalogy 31: 47-55.

McDowell, M.C. and Medlin, G.C. (2010). Natural resource management implications of the preEuropean non-volant mammal fauna of the southern tip of Eyre Peninsula, South Australia. Australian Mammalogy 32: 87-93.

McKenzie, N.L. and Bullen, R.D. (2009). The echolocation calls, habitat relationships, foraging niches and communities of Pilbara microbats. Records of the Western Australian Museum, Supplement 78: 123-155.

McKenzie, N.L., Hall, N.J. and Muir, W.P. (2000). Nonvolant mammals of the southern Carnarvon Basin, Western Australia. Records of the Western Australian Museum, Supplement 61: 479-510.

McKenzie, N.L. and Kerle, J.A. (1995). Golden-backed Tree-rat Mesembriomys macrurus (Peters, 1876) (pp 566-568). In: Strahan, R. (ed.). The mammals of Australia. 2nd edition. Reed Books: Chatswood, Australia.

McKenzie, N.L. and Muir, W.P. (2000). Bats of the southern Carnarvon Basin, Western Australia. Records of the Western Australian Museum, Supplement 61: 465-477.

McKenzie, N.L., van Leeuwen, S. and Pinder, A.M. (2009). Introduction to the Pilbara Biodiversity Survey, 2002-2007. Records of the Western Australian Museum, Supplement 78: 3-89.

Morton, S.R. and Martin, A.A. (1979). Feeding ecology of the barn owl, Tyto alba, in arid southern Australia. Australian Wildlife Research 6: 191-204.

Newsome, A.E. and Corbett, L.K. (1975). Outbreaks of rodents in semi-arid and arid Australia: causes, preventions, and evolutionary considerations (pp 117-153). In: Prakash, I. and Ghosh, P.K. (eds), Rodents in desert environments. W.Junk: Den Haag, The Netherlands.

Peters, W. (1876). Über die von S.M.S. Gazelle gesammelten Säugethiere aus den Abtheilungen der Nager, Hufthiere, Sirenen, Cetaceen und Beutelthiere. Monatsberichte der Königlichen Preussischen Akademie der Wissenschaften zu Berlin 1876: 355-366.

Reid, J.W.R., Kerle, J.A. and Baker, L. (1993). Mammals 
(pp 69-78). In: Reid, J.W.R., Kerle, J.A. and Morton, S.R. (eds), Uluru fauna: the distribution and abundance of vertebrate fauna of Uluru (Ayers Rock-Mount Olga) National Park, N.T. Kowari 4. Australian National Parks and Wildlife Service: Canberra, Australia.

Ride, W.D.L. (1959). A museum expedition to the Hamersley Range. The Australian Museum Magazine 13: 94-98.

Ride, W.D.L. (1964). Antechinus rosamondae, a new species of dasyurid marsupial from the Pilbara district of Western Australia; with remarks on the classification of Antechinus. The Western Australian Naturalist 9: 58-65.

\section{APPENDIX 1. EARLY PILBARA MAMMAL RECORDS FROM THE WESTERN AUSTRALIAN MUSEUM}

\section{Hamersley Expedition mammals}

Dasyurus hallucatus

M4518 Hamersley Range area 1958

Planigale sp.

M3432 Tambrey 3 Aug 1958 (Archer 1976, p. 357)

Pseudantechinus 'macdonnellensis'

M3430 Mount Herbert 27 Jul 1958

M3445 Coolawanyah Station 30 Jul 1958

Macropus robustus

M3503 Tambrey Station 31 Jul 1958

M3504 Coolawanyah Station 26 Jul 1958

M3505 Millstream Station 19 Jul 1958

M3506 Tambrey Station 31 Jul 1958

M3509 Millstream Station 16 Jul 1958

M3513 Coolawanyah Station 26 Jul 1958

M3514 Tambrey Station 29 Jul 1958

M3515 [Coolawanyah Station] 26 Jul 1958

M3516 Kangiangi Station 24 Jul 1958

M3517 Millstream Station 19 Jul 1958

M3518 Millstream 19 Jul 1958

M3519 Millstream 19 Jul 1958

M3523 Millstream 1958

M3526 Coolawanyah Station 4 Aug 1958

M3527 Millstream Station 20 Jul 1958

M3529 Coolawanyah Station 29 Jul 1958

M3530 Millstream Station 20 Jul 1958

M3559 Marillana Station Jul 1958

M3560 Marillana Station Jul 1958

M3561 Marillana Station Jul 1958

M3562 Marillana Station Jul 1958

M3564 Marillana Station Jul 1958

M3565 Marillana Station Jul 1958
Ride, W.D.L. (1968). On the past, present, and future of Australian mammals. Australian Journal of Science 31: 1-11.

Schodde, R. and Mason, I.J. (1980). Nocturnal birds of Australia. Lansdowne Press: Melbourne, Australia.

Serena, M. and Soderquist, T. (1995). Western Quoll Dasyurus geoffroii Gould, 1841 (pp 62-64). In: Strahan, R. (ed.). The mammals of Australia. 2nd edition. Reed Books: Chatswood, Australia.

Watts, C.H.S. and Aslin, H.J. (1981). The rodents of Australia. Angus \& Robertson: Sydney, Australia.

M3566 Tambrey (Station) 23 Jul 1958

M4958 Millstream (Station) 1958

M4959 Millstream (Station) 1958

M4960 Millstream (Station) 1958

M4961 Millstream (Station) 1958

M4962 Millstream (Station) 1958

29 records

Macropus rufus

M3507 Tambrey Station 4 Aug 1958

M3508 Marillana Station Jul 1958

M3528 Marillana Station Jul 1958

M4956 Kangiangi Station 21 Jul 1958

M4957 Millstream Station 1958

5 records

Pteropus alecto

M5125 Millstream Station 29 Jul 1958

M5126 Millstream Station 22 Jul 1958

M5127 Millstream Station 22 Jul 1958

M5128 Millstream Station 26 Jul 1958

M5129 Millstream Station 27 Jul 1958

M5130 Millstream Station 22 Jul 1958

M5131 Millstream Station 22 Jul 1958

M5132 Millstream Station 27 Jul 1958

8 records

Taphozous georgianus

M3431 Millstream Station 22 Jul 1958

M3448 Millstream Station 22 Jul 1958

M4749 Tambrey Station 30 Jul 1958

M4750 Tambrey Station 30 Jul 1958

4 records

Taphozous hilli

M4747 Tambrey Station 31 Jul 1958

Macroderma gigas

M3415 Tambrey Station 1 Aug 1958

M4413 Tambrey Station 4 Aug 1958 
Chalinolobus gouldii

M6310 Tambrey Station 3 Aug 1958

Vespadelus finlaysoni

M4751 Tambrey Station 30 Jul 1958

M4752 Tambrey Station 3 Aug 1958

Tim Ealey and co-worker specimens

Tachglossus aculeatus

M4932 Pullcunah Hill 24 Oct 1958 (R.M. Sadlier)

Dasycercus sp. indet.

M4268 Abydos Station Apr 1958

Dasykaluta rosamondae

M3416 Abydos Station 16 Aug 1956

M3421 Woodstock Station

M5507 Woodstock Station Oct 1957

M5508 White Springs Station Jul 1954

M5512 Woodstock Station Jun 1956

M5513 Woodstock Station 3 Apr 1957

M5514 Pullcunah Hill (near) 4 Apr 1958

M6054 Woodstock Station Apr 1957

M6055 Abydos Station 8 Nov 1956

9 records

Dasyurus hallucatus

M3469 Woodstock Station

M3501 Woodstock Station

M3502 Woodstock Station

M3571 Woodstock Station

M3651 Woodstock Station

M3652 Woodstock Station

M3653 Woodstock Station

M3654 Woodstock Station

M3655 Woodstock Station

M3656 Woodstock Station 28 Sep 1960

M3657 Woodstock Station

M3989 Woodstock Station 1958

M3993 Woodstock Station 23 Apr 1958

M6140 Woodstock Station 1958

M6141 Woodstock Station 10 Apr 1958

M6142 Woodstock or Mount Edgar Station

M10529 Woodstock Station

M10607 Woodstock Station

M10608 Woodstock Station

M10609 Woodstock Station

M10610 Woodstock Station

M10611 Woodstock Station

M10645 Woodstock Station
M10646 Woodstock Station

M10647 Woodstock Station

M10648 Woodstock Station

M10649 Woodstock Station

M10650 Woodstock Station

28 records

Ningaui timealeyi

M5076 Abydos Station Nov 1962

Pseudantechinus 'macdonnellensis'

M3659 Woodstock Station 25 Feb 1958

M5279 Woodstock Station 6 Feb 1958

M5509 Woodstock Station 25 Jan 1958

M5510 Woodstock Station 10 Feb 1958

M5769 Woodstock Station 1959

M6056 Woodstock Station 4 Apr 1958

6 records

Pseudantechinus roryi

M4291 Eginbah Station Aug 1959

M5280 Woodstock Station 6 Feb 1958

M5511 Woodstock Station 11 Feb 1958

Macrotis lagotis

M4196 Woodstock Station pick up, donated Sep 1960

Lagorchestes conspicillatus

M3496 accessed 1959

M3500 Woodstock Station accessed 1959

Macropus robustus

M4696 Woodstock Station 6 Nov 1959

M4697 Woodstock Station Nov 1959

M5840 Woodstock Station 2 Aug 1954

M6095 Mount Edgar Station 1958

M6096 Mount Edgar Station 1958

M6097 Mount Edgar Station 1958

M6098 Mount Edgar Station 1958

M6099 Mount Edgar Station 1958

M6100 Mount Edgar Station 1958

M6101 Mount Edgar Station 1958

M6102 Mount Edgar Station 1958

M6103 Mount Edgar Station 1958

M6104 Mount Edgar Station 1958

M6105 Mount Edgar Station 1958

M6106 Mount Edgar Station 1958

M6107 Mount Edgar Station 1958

M6108 Mount Edgar Station 1958

M6109 Mount Edgar Station 1958

M6110 Mount Edgar Station 1958 
M6111 Mount Edgar Station 1958

M6112 Mount Edgar Station 1958

M6113 Mount Edgar Station 1958

M6114 Mount Edgar Station 1958

M6115 Mount Edgar Station 1958

M6116 Mount Edgar Station 1958

M6117 Mount Edgar Station 1958

M6118 Mount Edgar Station 1958

M6119 Mount Edgar Station 1958

M6120 Mount Edgar Station 1958

M6121 Mount Edgar Station 1958

M6122 Mount Edgar Station 1958

M6123 Mount Edgar Station 1958

M6124 Mount Edgar Station 1958

M6125 Mount Edgar Station 1958

M6126 Mount Edgar Station 1958

M6127 Mount Edgar Station 1958

M6128 Mount Edgar Station 1958

M6129 Mount Edgar Station 1958

M6130 Mount Edgar Station 1958

M6131 Mount Edgar Station 1958

M6132 Mount Edgar Station 1958

M6133 Mount Edgar Station 1958

M6134 Mount Edgar Station 1958

M6135 Mount Edgar Station 1958

M6136 Mount Edgar Station 1958

M6137 Mount Edgar Station 1958

M6138 Mount Edgar Station 1958

M6139 Mount Edgar Station 1958

M6171 Mount Edgar Station 1958

M6172 Mount Edgar Station 1958

M6173/1 Mount Edgar Station 3 Mar 1960

M6173/2 Mount Edgar Station 3 Mar 1960

M6246 Woodstock or Mount Edgar Station 1958

53 records

Macropus rufus

M3510 Woodstock Station 2 Oct 1955

M3511 accessed 1959

M6170 Mount Edgar or Woodstock Station 1 May 1955

Petrogale rothschildi

M3324 Woodstock Station

M3325 Woodstock Station

M3499 Woodstock Station

M3650 Woodstock Station

M3881 Pullcunah Hill 18 Sep 1957

M4259 Pullcunah Hill 21 Nov 1959

M4274 Pullcunah Hill 3 Dec 1957
M4287 Woodstock Station 4 Dec 1957

M4440 Woodstock Station

M4443 Woodstock Station Feb 1958

M6220 Woodstock Station 5 Oct 1957

11 records

Pseudomys chapmani

M5767 Mount Edgar Station 8 Oct 1957

M5864 White Springs Station 18 Sep 1956

M5865 White Springs Station 18 Sep 1956

M5866 White Springs Station 18 Sep 1956

M5867 White Springs Station 18 Sep 1956

M5868 White Springs Station 18 Sep 1956

M5870 White Springs Station 18 Sep 1956

7 records

Pseudomys hermannsburgensis

M3452 Woodstock Station accessed 1959

Zyzomys argurus

M3296 Woodstock Station Dec 1957

M5733 Woodstock Station 24 Jan 1958

M5739 Woodstock Station 12 Dec 1957

M5740 Woodstock Station 16 Dec 1957

M5741 Woodstock Station 28 Jan 1958

M5749 Woodstock Station 1959

M5750 Woodstock Station 1959

M5751 Woodstock Station 1959

M5752 Woodstock Station 1959

M5753 Woodstock Station 1959

M5754 Woodstock Station 1959

M5755 Woodstock Station 1959

M5756 Woodstock Station 1959

M5757 Woodstock Station 1959

M5758 Woodstock Station 1959

M5759 Woodstock Station 16 Dec 1957

M5760 Woodstock Station 1957

M5761 Woodstock Station 1957

M5762 Woodstock Station 21 Jan 1958

M5763 Woodstock Station 6 Feb 1958

M5764 Woodstock Station 17 Dec 1957

21 records

Other records

Sminthopsis youngsoni

M32738 Woodstock Station 2 Mar 1990

Trichosurus vulpecula

M2767 Red Hill Station 22 $08^{\prime}$ S $116^{\circ} 04^{\prime}$ E 1948

M19550 Bonney Downs 2210'S 11956'E 1981 